\title{
ZNACZENIE METOD LITOLOGICZNYCH W REKONSTRUKCJACH PROCESÓW GLACIGENICZNYCH NA PRZYKLADACH Z OBSZARU STAROGLACJALNEGO POLSKI ŚRODKOWEJ
}

\author{
The importance of lithological methods in the reconstruction \\ of glacigenic processes of the old glacial area with examples from Central Poland
}

ZBIGNIEW RDZANY*, MAŁGORZATA FRYDRYCH*

\begin{abstract}
Zarys treści. W artykule przedstawiono ewolucję stosowanych metod litologicznych w rekonstrukcjach paleogeograficznych procesów glacigenicznych w Polsce Środkowej. Zaproponowano szersze stosowanie metody litofacjalnej i litogenetycznej w powiązaniu z określeniem zapisu poziomu energii w środowisku sedymentacji. Stwierdzono, że wyróżniane na podstawie poziomu energii litotypy wykazują powiązania zarówno z określonymi rodzajami środowisk sedymentacyjnych, jak i grupami genetycznymi form rzeźby. Stosując metodę zapisu litologicznego z uwzględnieniem ustalenia poziomu energii środowiska, autorzy przyjęli wydzielenie czterech głównych litotypów: 1) bardzo wysokiej, 2) wysokiej, 3) średniej, i 4) niskiej energii. Autorzy przedstawili wnioski z zastosowania tej typologii w różnych odsłonięciach, dostrzegając przede wszystkim jej przydatność w zakresie wnioskowania paleogeograficznego.
\end{abstract}

Słowa kluczowe: zlodowacenie odry, litogeneza, środowisko wysokoenergetyczne, region łódzki

\begin{abstract}
The article presents an evolution of the experience in the application of lithological methods for palaeogeographic reconstructions of glacigenic processes in Central Poland as well as a proposal for a wider use of the lithofacies and lithogenetic analyses in connection with determining the energy level record in sedimentation environments. It was found that the lithotypes distinguished on the basis of energy level show connections both with specific sedimentation environment types and with genetic groups of relief forms. By applying the method of lithological record with determining the environment energy level, the authors assumed the distinction of four main lithotypes: 1) very high, 2) high, 3) medium, and 4) low energy. The authors analysed the positive and negative conclusions from the application of this typology in different outcrops, noticing a number of advantages for palaeogeographic inference.
\end{abstract}

Keywords: Odra glaciation, lithogenesis, high-energy environment, Łódź region

\section{Wprowadzenie}

Rekonstrukcje paleogeograficzne i badania z zakresu stratygrafii są możliwe dzięki świadectwom procesów zapisanych $\mathrm{w}$ cechach osadów, $\mathrm{w}$ tym także śladom życia organicznego. W utworach plejstoceńskich, w porównaniu z osadami starszymi, występuje ubóstwo, a nawet często zupełny brak zapisów życia organicznego. Mówi się o tych utworach, zwłaszcza pochodzących ze środowisk sedymentacji w klimatach zimnych, że są ,nieme paleontologicznie". Osady biogeniczne, zawierające cenne w badaniach szczątki organizmów występują w tych utworach tylko lokalnie, a ich nagromadzenia reprezentują stosunkowo krótkie interwa- ły czasowe. W związku z tym, wykorzystanie różnych właściwości osadów mineralnych dla celów rozwiązywania problemów paleogeografii i stratygrafii plejstocenu jest bardzo powszechne i różnorodne. Poza tym każdy region, w którym występują osady plejstoceńskie, odznacza się specyfiką ich typów litologicznych, zróżnicowaniem wiekowym oraz różnym stopniem przekształcenia czynnikami postsedymentacyjnymi. W niniejszym artykule wzięto pod uwagę obszar Polski Środkowej, stanowiący pas rzeźby staroglacjalnej (tzw. warciańskiej i odrzańskiej) między Wysoczyzną Kaliską a Rawską. Jest on wewnętrznie, lokalnie zróżnicowany w sensie zarówno morfometryczno-morfograficznym, jak i genetycznym (różne subśrodowiska morfogenezy glacjalnej, zróżnicowane

\footnotetext{
* Uniwersytet Łódzki, Wydział Nauk Geograficznych, Katedra Geografii Fizycznej, ul. Narutowicza 88, 90-139 Łódź; e-mail: zbigniew.rdzany@geo.uni.lodz.pl; malgorzata.frydrych@geo.uni.lodz.pl
} 
nałożenie morfogenezy peryglacjalnej na formy glacjalne itd.).

Jako główne cele artykułu przyjęto przedstawienie ewolucji doświadczeń w stosowaniu metod litologicznych w rekonstrukcjach paleogeograficznych kompleksu środkowopolskiego (pięter warty i odry) na przykładach z Polski Środkowej (rys. 1) oraz analizę przydatności metod litofacjalnej i litogenetycznej w ujęciu, które uwzględnia ustalenie poziomu energii środowiska.

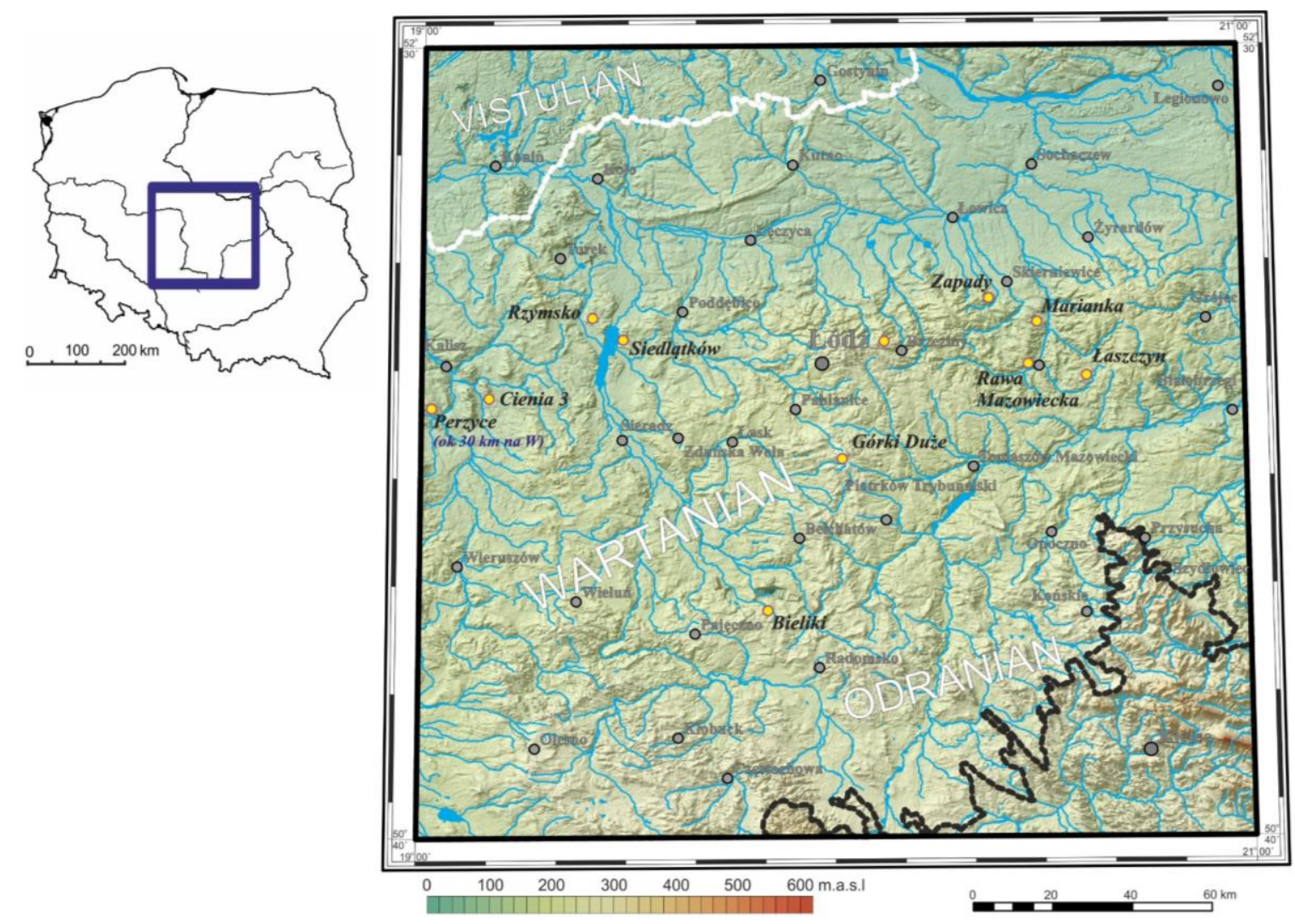

Rys. 1. Położenie prezentowanych stanowisk na tle zasięgu maksymalnego zlodowacenia wisły (linia czarna) i odry (linia białą) (wg Marksa 2005, zmienione)

nazwy stanowisk opisano kursywą

Location of the presented sites in relation to the maximum extent of the Wartanian (black line) and Odranian (white line) glaciations (after Marks 2005, modified)

site names are written in italic

W niniejszej pracy dokonano przeglądu metod litologicznych, z którego wynika, że ich spektrum tematyczne i stopień przydatności do celów paleogeograficznych zmieniały się okresowo (np. Dylikowa 1952; Klatkowa 1982; Goździk 1995a; Jaksa 2006; Rdzany 2009; Frydrych 2016). Szukając nowych możliwości wnioskowania paleogeograficznego, przeanalizowano także przykłady zastosowania metod łączonych. Autorzy proponują w szczególności stosowanie metody litofacjalnej z metodą litogenetyczną. Jest to przydatne do rekonstrukcji środowisk, cechujących się charakterystycznymi śladami zapisu poziomu energii w środowisku. Przedstawiono tezę, że owe ślady (struktury, tekstury), skoncentrowane na danym terenie zawierają ważne informacje paleogeograficzne dotyczące zarówno środowiska sedymentacji, jak i stanu dynamicznego części lądolodu (lobu).

\section{Przykłady zastosowań metod litolo- gicznych w badaniach osadów glaci- genicznych kompleksu środkowo- polskiego w Polsce Środkowej}

Postęp wiedzy o litologii i litostratygrafii utworów kompleksu środkowopolskiego, w szczególności piętra warty w Polsce Środkowej, nie licząc 
pojedynczych prac z międzywojnia, ma historię sięgającą pierwszych lat po II wojnie światowej. Rozpoczęto wówczas opracowywanie map geologicznych oraz terenowe badania rzeźby. Początkowo jednak były to badania ukierunkowane głównie na rekonstrukcje środowiska peryglacjalnego, a w mniejszym stopniu - glacjalnego. Od lat 60. nastąpił jednak szybki wzrost zainteresowania osadami glacigenicznymi w tym regionie. Powstawały kolejne monografie $\mathrm{z}$ zakresu geomorfologii glacjalnej i geologii czwartorzędu, w znacznej części lub całkowicie poświęcone poszczególnym typom form i osadów warciańskich (m.in.: Krzemiński 1965; Klajnert 1966; Klatkowa 1972). Jeszcze większą aktywność badań odnotować można w latach 80. ubiegłego stulecia. Wśród badaczy regionu, stosujących szeroko różne metody litologiczne, miejsce szczególne zajmuje profesor Halina Klatkowa.

W 1982 r. Klatkowa przedstawiła tezę o powszechnym występowaniu w regionie łódzkim serii ablacyjnej o miąższości 2-4 m, która tworzy górną część utworów zlodowacenia warty. Poziom ten, występujący na pagórkach kemowych, na stokach form morenowych i na równinach glacifluwialnych, powiązała wiekowo $\mathrm{z}$ deglacjacją lądolodu warty. Seria ta zawiera powszechnie występujące różnorodne struktury deformacyjne. $\mathrm{Z}$ punktu widzenia tekstury najczęściej tworzą ją gliny piaszczyste, piaski gliniaste i muły. Na podstawie tych cech Klatkowa (1982) wydzieliła pięć typów facjalnych, którym można przyporządkować określony sposób powstania w warunkach deglacjacji. Utwory te znane i badane były już wcześniej, m.in. przez Klajnerta (1966) na obszarze kemowych Wzgórz Domaniewickich. Autor interpretował je jako serię jednorodną pod względem genezy, będącą wynikiem przemieszczania się „błota ablacyjnego” z nieaktywnego lodu lodowcowego na osady glacifluwialne. Badania Klatkowej (1982) umożliwiły rozpoznanie w ich obrębie pięciu głównych litofacji. Są to: a) glina ablacyjna, powstała in situ w wyniku powolnego parowania i wytapiania lodu, b) piaski gliniaste masywne, powstałe przy dużym nasyceniu wodą, c) mułki ablacyjne, powstałe w płytkich zbiornikach z rzadkiego „błota ablacyjnego”, d) osady różnoziarniste o charakterze pakietów, odkładane przy dużym udziale pogrzebanych brył martwego lodu, oraz: e) osady, deponowane przez wody ablacyjne, a następnie deformowane na nachylonych powierzchniach. Seria ablacyjna przykryta jest często utworami vistulianu, niekiedy bezpośrednio - holocenu, o genezie stokowej, fluwialnej lub eolicznej. W pozycji przypowierzchniowej nosi także liczne znamiona przekształceń w wyniku ruchów gruntu, procesów wietrzenia i innych procesów glebotwórczych okresu postwarciańskiego.

Warto zwrócić uwagę na charakterystyczną metodę dokumentowania cech osadów, stosowaną przez Klatkową (np. 1982) (rys. 2). Metoda nawiązywała do zasad dokumentowania obiektów w archeologii i wcześniej była używana również przez Dylika (np. 1952), Dylikową (np. 1956) i innych badaczy ośrodka łódzkiego w pracach nad rekonstrukcjami środowiska peryglacjalnego. Polegała na bardzo dokładnym, wręcz drobiazgowym odrysowaniu elementów tekstury i struktury osadów, a także ich barwy. Chociaż czasochłonna, okazała się szczególnie przydatna. Obecnie, w dobie wysokorozdzielczej fotografii cyfrowej, straciła na znaczeniu, choć nie ma przeciwwskazań do jej stosowania. Należy zauważyć, że na podstawie tak dokładnych rysunków można dokonywać zaawansowanych analiz lub przekształcić w inny rodzaj dokumentacji, np. sporządzając zapis za pomocą kodu litofacjalnego Mialla (1978).

W tym samym czasie próbę uchwycenia cech litofacjalnych $\mathrm{w}$ glinach lodowcowych deponowanych przez lądolód warciański w lobie Widawki przeprowadził także Nalewajko (1982), poddając je badaniom strukturalnym (makro- i mezostrukturalnym) w odsłonięciach oraz badaniom teksturalnym (uziarnienie, morfoskopia, uproszczony skład mineralny $i$ in.). Pozwoliło to na wyodrębnienie litofacji, kompleksów i subkompleksów litofacjalnych, a także na odnotowanie prawidłowości regionalnego występowania zespołów o podobnych cechach litofacjalnych. Autor nie przedstawił jednak bardziej zdecydowanych i szerszych wniosków paleogeograficznych, uznając, że ma zbyt małą liczbę danych (Nalewajko 1982).

W ramach prac nad Szczegółową mapą geologiczną Polski (SMGP) przez wiele lat były prowadzone w Polsce Środkowej badania glin lodowcowych, ukierunkowane na doprecyzowanie wieku i stratygrafii poszczególnych ich poziomów, za sprawą oznaczeń petrograficznych frakcji drobnych żwirów $(5-10 \mathrm{~mm})$. Badania te, mimo znacznej liczby dokonanych oznaczeń a także różnych modyfikacji i udoskonaleń metodycznych, nie pozwoliły jednak na rozstrzygnięcie szeregu problemów stratygraficznych (Kenig 1999; Lisicki 2003). 


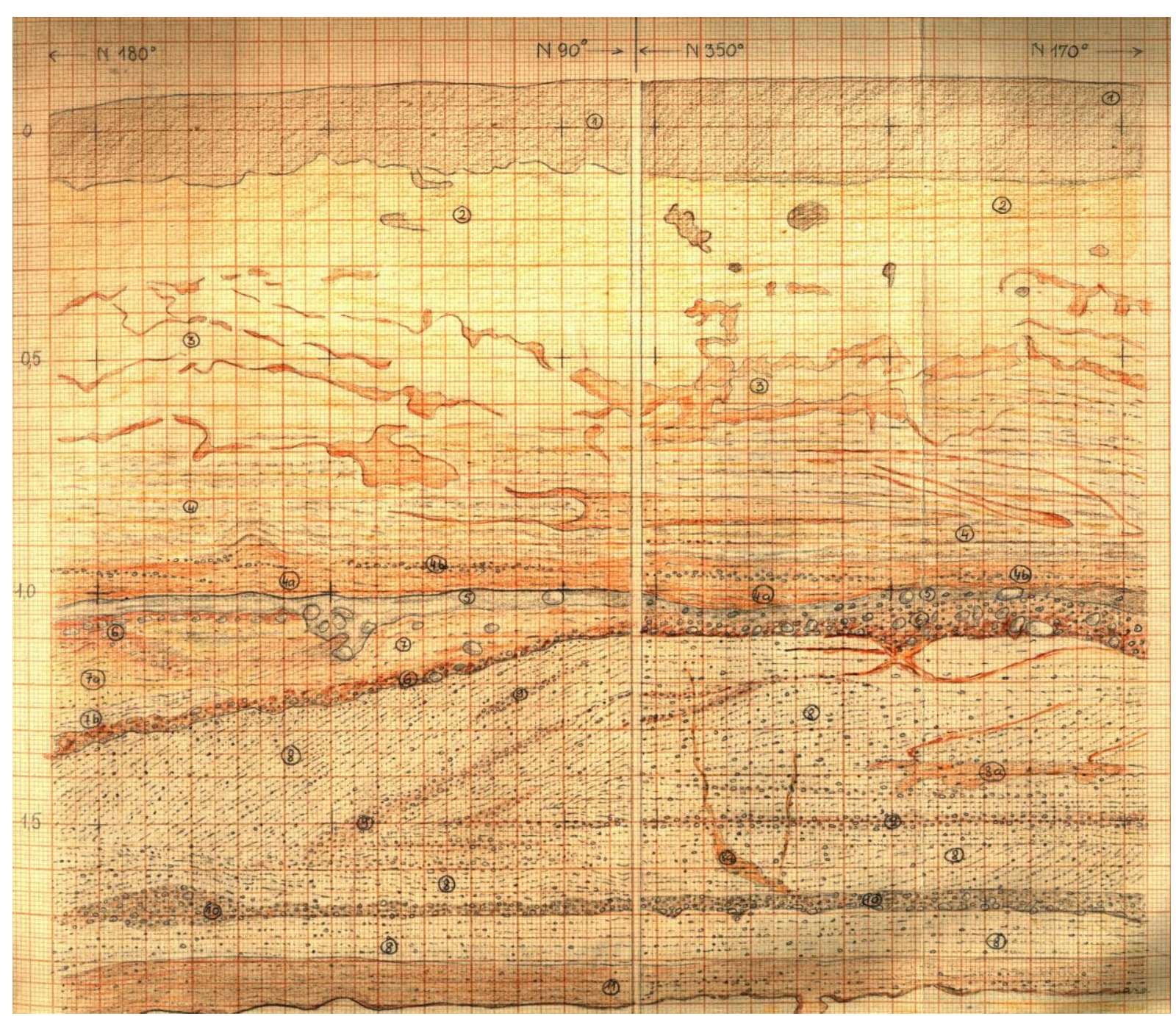

Rys. 2. Rysunek ścian szurfu w Jabłonowie H. Klatkowej z 1957 r. (mat. arch. autorki) - przykład szczegółowej dokumentacji rysunkowej cech litologicznych osadu

A drawing of trenching walls in Jabłonów by H. Klatkowa of 1957 (archive materials of the author) - an example of detailed drawing documentation of lithological features of the sediment

Większe nadzieje na postęp w stratygrafii plejstocenu wzbudziły badania eratyków frakcji średnich i grubych żwirów występujących w glinach lodowcowych, podjęte dla Polski Środkowej przez Czublę (2001). Autor następnie poszerzył zasięg regionalny badań (od Dolnego Sląska po Podlasie) i udoskonalił metodologię, m.in. co do odniesień wyników analiz eratyków przewodnich do nowych modeli dynamiki lądolodu (Czubla 2015).

W ostatnich latach podjęte zostały także badania petrograficzne średniej i grubej frakcji żwirowej w utworach glacifluwialnych na obszarze między Piotrkowem Trybunalskim, Przedborzem a Radomskiem (Górska-Zabielska, Wachecka-Kotkowska 2015). Wyniki tych badań wsparły wcześniejszą hipotezę Turkowskiej (2006) o zróż- nicowaniu lobów lądolodu warty na tym obszarze. Prace te dowiodly przede wszystkim niewielkiego zróżnicowania petrograficznego żwirów. Mimo że na ich podstawie podjęto nawet próbę ustalenia TCG (teoretycznego centrum głazowego), nawiązując do metody Lüttiga (1958), należy zauważyć, że nie powinny być traktowane jako równoważne $\mathrm{z}$ badaniami petrografii żwirów w glinach lodowcowych. Do zastosowanej metodologii badań petrografii żwirów glacifluwialnych (Górska-Zabielska, Wachecka-Kotkowska 2015) krytycznie odniósł się Czubla (2015), zwracając uwagę na występowanie szerszego spektrum petrograficznego w żwirach glacifluwialnych w porównaniu do żwirów z glin lodowcowych. Również obserwacje autorów, przeprowadzone w kilku ozach i wypełnieniach rynien subglacjalnych Polski Środkowej, 
wskazują na zdecydowanie zwiększony udział klastów z lokalnych skał mezozoicznych w stosunku do eratyków pochodzenia północnego w porównaniu z glinami. W skrajnym przypadku udział eratyków lokalnych w materiale ozu osiągał blisko 90\% (Rdzany 2009; Frydrych 2016).

Metoda petrograficzna w modyfikacji zastosowanej przez Czublę $(2001,2015)$ w odniesieniu do glin lodowcowych przynosi pozytywne rezultaty - może w pewnych przypadkach wręcz rozstrzygać poważne wątpliwości stratygraficzne. Przykładem jest stanowisko Besiekierz, gdzie analiza petrograficzna diamiktonu o cechach warciańskiej gliny lodowcowej, leżącego na organicznych osadach eemskich pozwoliła wyjaśnić genezę (wtórne przemieszczenia i zmiany wietrzeniowe) oraz wiek tego osadu (Czubla i in. 2013). Należy jednak zauważyć, że pracochłonność metody, konieczność żmudnych prac przygotowawczych i słaba dostępność w Polsce Środkowej odpowiednich odsłonięć stwarza znaczne ograniczenie jej stosowania.

Biorąc pod uwagę wykształcenie litofacjalne osadów warciańskich analizowane w kontekście typów genetycznych warciańskich form glacjalnych, najbardziej precyzyjny obraz uzyskano dla kemów, które należą do pospolitych form rzeźby regionu. Badania kemów dostarczyły danych wskazujących na powtarzające się zespoły struktur zarówno wertykalnie, jak i lateralnie. Charakterystyczne układy struktur w przekrojach form udokumentował Klajnert (1978) we wschodniej części Wzniesień Łódzkich. Zaobserwował regularną obecność niezaburzonych utworów glacifluwialnych we wnętrzu kemów oraz występowanie po obydwu ich stronach - w brzeżnych częściach form - zaburzonych utworów kontaktu lodowego. Deformacje te mają $\mathrm{z}$ reguły charakter grawitacyjny, związany z kurczeniem się mas lodu martwego lub stagnującego. Ponadto autor stwierdził w zewnętrznych częściach kemów pokrywy ablacyjne, które stanowią także dowód na kurczenie się martwych lodów i gromadzenie się materiału mineralnego $\mathrm{z}$ ich topnienia. $\mathrm{W}$ profilach badanych kemów odnotował częste występowanie tzw. „układu wstępującego”, wyrażającego się wzrostem średniej średnicy ziaren ku górze profilu, na przykład od mułów, poprzez piaski do żwirów. Taki układ osadów pozwala zrekonstruować warunki i przebieg sedymentacji wodnolodowcowej oraz proces powstawania kemów w trakcie degradacji lądolodu. Późniejsze badania nad zróżnicowaniem litofacjalnym kemów, także podjęte przez innych autorów, poszerzyły wiedzę o szereg kolejnych wniosków dotyczących środowisk ich sedy- mentacji (m.in.: Krzemiński 1974; Klajnert 1984; Rdzany 1997; Jaksa 2006).

W Polsce Środkowej badano też ozy, sandry, moreny czołowe, rynny subglacjalne, formy przejściowe (np. ozowo-kemowe), a także formy o budowie złożonej.

Ozy Polski Środkowej poddane zostały analizom jako poszczególne formy (Zaborski 1926; Baraniecka, Sarnacka 1971; Turkowska 1984; Jaksa, Rdzany 2002; Jaksa 2003; Frydrych 2016) oraz w związku z pracami kartograficznymi nad SMGP (np. Czyż i in. 2008). W starszej literaturze profile ich osadów były dokumentowane głównie pod względem cech teksturalnych. Wykazywano duży udział słabo wysortowanych utworów żwirowo-piaszczystych. Obecnie prowadzone badania nad ozami na obszarze Polski Środkowej z zastosowaniem analizy litofacjalnej ukazują znaczne zróżnicowanie pod kątem zapisu dynamiki transportu osadów i ich sedymentacji. Udokumentowano przepływy od bardzo wysokoenergetycznych, nawet typu katastrofalnego do niskoenergetycznych - charakterystycznych dla form pośrednich ozowo-kemowych (Jaksa, Rdzany 2002; Jaksa 2006; Frydrych 2016).

Problematyka zróżnicowania utworów moren czołowych uzyskała częściowe rozwiązanie, tym bardziej że istnieje w Polsce Środkowej niewiele przykładów form zgodnie zaliczanych do tej kategorii. Według pierwszych badaczy rzeźby glacjalnej regionu, formy tej genezy były uznawane za liczne (Lencewicz 1927; Balińska-Wuttke 1960; Różycki 1961). Jednakże Dylik (1953), zgodnie z koncepcją denudacji peryglacjalnej, nawet największe z nich określił jako ostańce peryglacjalne, choć brał pod uwagę taką właśnie genezę pierwotną. Z kolei według Klajnerta (1966, 1978), zarówno stwierdzone cechy strukturalne, jak i teksturalne, są wystarczającą podstawą uznania wielu tych form (np. Wzgórz Domaniewickich) za kemy i wiązania ich powstania z procesem deglacjacji arealnej.

Również wiedza o sandrach regionu nie jest satysfakcjonująca. Podobnie jak w przypadku ozów, istotne informacje wnoszą wyniki szczegółowego kartowania geologicznego. Z map tych, a także niektórych monografii i artykułów (np. Klatkowa 1972; Rdzany 2006, 2009; Wachecka-Kotkowska 2015) wynika, że sandry mają często charakter form nieregularnie rozmieszczonych, $\mathrm{z}$ reguły niezwiązanych w sposób czytelny ani morfologicznie, ani litologiczne z wyraźnymi strefami marginalnymi.

Duże znaczenie w rekonstrukcjach paleogeograficznych mają także glacitektoniczne struktury 
deformacyjne, występujące w osadach kompleksu środkowopolskiego, w szczególności piętra warciańskiego (m.in.: Klatkowa 1993, 1996; Załoba, Czubla 1995; Załoba 1996; Ber 2006). Cechą charakterystyczną wielkoskalowych zaburzeń, obejmujących osady zlodowacenia warty jest ich strefowe występowanie i zdecydowana przewaga struktur plastycznych nad kruchymi. W przypadku zaburzeń o dużej amplitudzie nie zawsze jest jednak jasne, kiedy powstały. Istnieje bowiem prawdopodobieństwo wyeksponowania przez procesy niszczące starszych struktur plejstoceńskich. Najmniej kontrowersji co do wieku budzą struktury deformacyjne typu diapirów i dajek klastycznych występujące $\mathrm{w}$ formach $\mathrm{z}$ ostatniej deglacjacji, często całkowicie przebijające osady form warciańskich (Rdzany $i$ in. 2015).

Geneza struktur glacitektonicznych może być bardzo złożona i wyjaśniana różnymi teoriami. Na przykład udokumentowany w okolicach Pabianic i Kudrowic zespół form zwany glacitektonoparą (Klatkowa 1996), czy zaburzenia glacitektoniczne wnętrza Wzgórz Ostrzeszowskich (Rotnicki 1967, 1976) mogą służyć jako przykłady statyki i dynamiki frontalnej. Obserwowane przez autorów dajki i diapiry na krawędzi doliny dolnej Pokrzywnicy na południe od Opatówka oraz na krawędzi doliny Miazgi wzdłuż ozu (a jednocześnie rynny subglacjalnej) Łaznowskiej Woli - to z kolei przykłady struktur, które mogą być interpretowane zarówno jako wynik glacitektoniki krawędziowej, jak i tzw. hydroglacitektoniki (Dadlez, Jaroszewki 1994).

Oprócz samego zróżnicowania typów strukturalnych i genetycznych zaburzeń glacitektonicznych w opisywanych osadach glacigenicznych występuje szereg innych struktur deformacyjnych, których geneza może być trudna do ustalenia, a wiek zróżnicowany. Dość dobrze zostały poznane struktury zaburzeń peryglacjalnych, które powstały postsedymentacyjnie, znacznie później głównie $\mathrm{w}$ vistulianie. Istnieją także struktury peryglacjalne, np. mrozowe, powstałe synchronicznie z osadami glacifluwialnymi (m.in.: Goździk 1995b; Wachecka-Kotkowska 2015).

Odrębnym problemem jest zagadnienie deformacji związanych z procesami paraglacjalnymi, które miały miejsce u schyłku deglacjacji lądolodu warciańskiego i później, ale przed bujnym rozwojem roślinności $\mathrm{w}$ interglacjale eemskim. $\mathrm{Na}$ istnienie takich struktur (np. związanych z procesami stokowymi) w Polsce Środkowej dopiero od kilku lat zwraca się uwagę (Rdzany 2015). Słabe rozpoznanie zapisu procesów paraglacjalnych przełomu pięter warta/eem stanowi niewątpliwą lukę w badaniach osadów warciańskich tego obszaru.
Podsumowując, należy stwierdzić, że w miarę postępu prac badawczych od międzywojnia do czasów nam współczesnych oraz rozwoju wiedzy o osadach i paleogeografii pięter zimnych kompleksu środkowopolskiego, zmieniały się i modyfikowały zarówno metody badań, jak i ich cele. W ciągu ostatnich kilkunastu lat nabrała znaczenia metoda litofacjalna, która znacząco poprawiła możliwości wnioskowania paleogeograficznego. Ustalenie cech litologicznych osadów pomaga zrekonstruować genezę danej formy glacjalnej, choć często najlepszy efekt daje połączenie jej z innymi metodami. Autorzy uważają, że pozytywne rezultaty przynosi poszerzenie metody litofacjalnej o metody litogenetyczne, zwłaszcza jeśli wyniki tych analiz będą pogrupowane w kontekście zapisu dynamiki procesów glacigenicznych oraz w odniesieniu do typów genetycznych form.

\section{Metody}

W niniejszej pracy głównym obiektem badań były odsłonięcia osadów glacigenicznych, które zostały opisane za pomocą kodu litofacjalnego. $\mathrm{Na}$ podstawie wyników analizy litofacjalnej opracowywano interpretację litogenetyczną. Zastosowanie kodu litofacjalnego i litogenetycznego odpowiadało zasadom przedstawionym przez Mialla (1978, 1985) w modyfikacji Zielińskiego (2014). Opis symboli zastosowanych $\mathrm{w}$ artykule przedstawia tab. 1.

Następnie badane profile pogrupowano zarówno według poziomu energii procesów zapisanych w cechach osadów, jak i według kategorii genetycznych form rzeźby, w których występowały. Poziom energii był określany opisowo, głównie nawiązując do mocy strumienia, reprezentowanego przez określone zestawy litofacji. Szeroki zakres zmian według poziomu energii autorzy sprowadzili do czterech głównych typów litologicznych (litotypów): 1) bardzo wysokiej, 2) wysokiej, 3) średniej i 4) niskiej energii.

Litotypy bardzo wysokiej energii (1) wyróżniano w przypadku m.in.: zapisu rozległych powierzchni erozyjnych (rynien), litofacji świadczących o warunkach nadkrytycznych, wielkiej skali warstwowań, o wysokim wskaźniku MPS (Maximum Particle Size; parametr obliczany jako średnia z 10 największych ziaren), złym wysortowaniu oraz z innymi cechami, które mogą świadczyć np. o dnie antywydmowym, czy poprzecznych pręgach żwirowych. Litotypy wysokiej energii (2) to litofacje powstałe głównie w warunkach górnego płaskiego dna, często akumulowane z przesłony 
Kod litofacjalny i litogenetyczny (za Miallem 1985 i Zielińskim 2014)

Lithofacies and lithogenetic code (after Miall 1985 and Zieliński 2014)

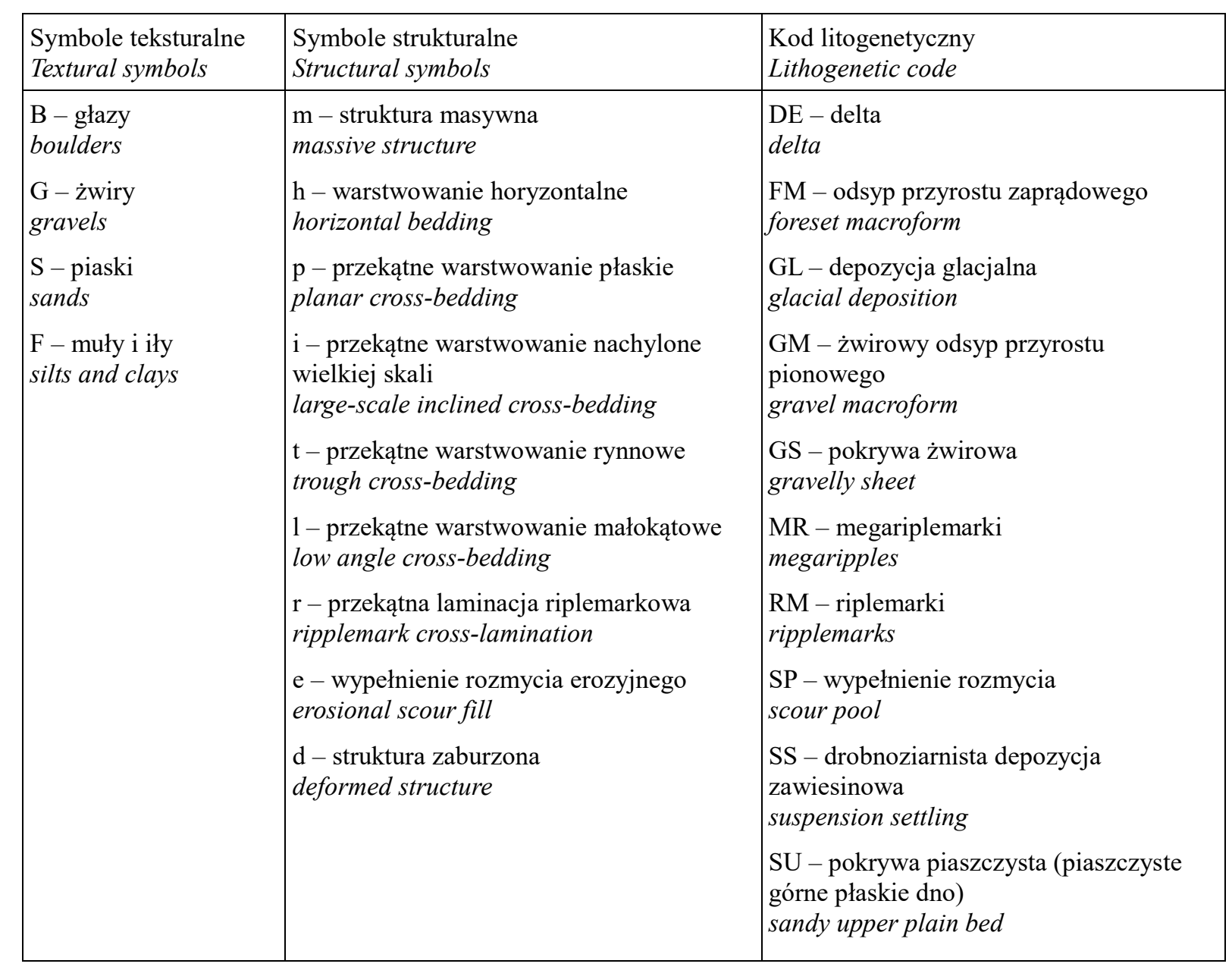

trakcyjnej. W profilach mogły się pojawiać litofacje o niewielkim udziale przepływu podkrytycznego (struktury związane $\mathrm{z}$ megariplemarkami). Do litotypów średniej energii (3) zaliczano głównie litofacje będące zapisem odsypów żwirowych i piaszczystych oraz megariplemarków. Litotypy niskiej energii (4) to zapis dolnego reżimu przepływu, w którym tworzyły się głównie riplemarki, ewentualnie piaszczyste megariplemarki, odsypy foresetowe $\mathrm{i}$ inne człony delt oraz następowała akumulacja bez przepływu - opadanie z zawiesiny w stojącej wodzie.

Oprócz zbadania profili osadów kompleksu środkowopolskiego (głównie zlodowacenia warty) w czynnych odsłonięciach, wykorzystano także w celach porównawczych różnorodne materiały archiwalne i profile litologiczne, zawarte w publikacjach.

\section{Wyniki analiz litologiczno-litogene- tycznych i ich interpretacja paleo- geograficzna}

Zbadane profile osadów w różnych typach form glacigenicznych pozwoliły na ich pogrupowanie zarówno w odniesieniu do kategorii genetycznych form, jak i w odniesieniu do przyjętych kryteriów wyróżniania poziomu energii. Przeanalizowane profile osadów z powodu ograniczeń wynikających z głębokości i dostępności odsłonięć $\mathrm{z}$ reguły nie obejmowały pełnego profilu stratygraficznego piętra środkowopolskiego. Niniejszy przegląd zawiera charakterystyczne przykłady i ich interpretacje paleogeograficzne. 


\section{Litotypy bardzo wysokiej energii}

Litotypy te stwierdzono w odsłonięciu klifu zbiornika Jeziorsko w Siedlątkowie w osadach powodzi glacjalnej (jökulhlaup), rozcinających wysoczyznę morenową oraz $\mathrm{w}$ pobliskim ozie Rzymska.

Najwyższa energia środowiska miała miejsce podczas powodzi glacjalnych, do których dochodziło zarówno na przedpolu lodowca, jak i w tunelach subglacjalnych. Zapis osadowy takiego zdarzenia różni się w zależności od miejsca występowania. Udokumentowane powodzie glacjalne, występujące na przedpolu lądolodu zapisały się jako kilkumetrowej miąższości osady żwirowo-głazowe o strukturze masywnej i przeważnie rozproszonym szkielecie ziarnowym, mające rozciągłość poziomą do kilkuset metrów. W osadach tych występuje często w dolnej części profilu uziarnienie frakcjonalne odwrócone, a w górnej części - uziarnienie normalne (rys. 3A i B). Taka sekwencja osadów uznawana jest za typową dla osadów powodziowych typu jökulhlaup (m.in. Maizels 1997). Na obszarze Polski Środkowej stwierdzono ja do tej pory jedynie w Siedlatkowie (Rdzany 2009; Frydrych 2014). Osady tego typu rozcinają przeważnie powierzchnię wysoczyzny lub występują w miejscu wypływu wód lodowcowych - w proksymalnej części sandrów. Stanowią zatem dobry wyznacznik bliskości czoła lądolodu, a co za tym idzie - są stosunkowo latwo rozpoznawalne $\mathrm{i}$ charakterystyczne dla strefy marginalnej. Ich występowanie w odsłonięciach na terenie Niżu Polskiego jest bardzo rzadkie, a w strefie staroglacjalnej ogranicza się zaledwie do kilku przypadków (Zieliński 2014; Orłowska 2017).

Bardzo wysoka (ekstremalna) energia przepływu występuje również podczas wezbrań subglacjalnych i ma swój zapis w osadach ozów. Na obszarze Polski Środkowej występuje niewiele ozów, w których znaleźć można dowody na transport i akumulację w warunkach bardzo wysokiej energii przepływu. Charakteryzują się one występowaniem sekwencji masywnych żwirów i głazów ze zmiennym udziałem piaszczystej lub piaszczysto-żwirowej matriks $\mathrm{w}$ dolnej części profilu. Osad ten uznawany jest za typowy dla środowiska tunelu subglacjalnego (Brennand 1994; Delaney 2001). Powyżej występuje wielometrowa sekwencja przekątnie płasko warstwowanych żwirów z głazami oraz żwirów dobrze wysortowanych o zwartym szkielecie ziarnowym $\mathrm{z}$ często występującą teksturą typu openwork. Osady te przewarstwione bywają osadami litofacji przekątnie płasko warstwowanych piasków ze żwirem i piasków (SGp, Sp) oraz przeważnie nadbudowane są drobniejszymi osadami piaszczystymi (Sh, Sr). Przykład typowego profilu osadów ozu powstałego w środowisku wysokoenergetycznym przedstawia rysunek 3C i D.

\section{Litotypy wysokiej energii}

Litotypy te stwierdzono w kilku stożkach marginalnych, ozach oraz w sandrach (stanowisko Marianka). Badane stożki marginalne charakteryzuje naprzemienna sedymentacja żwirów i piasków, wyrażająca rytmiczną zmienność w dostarczaniu materiału i energii wód ablacyjnych w strefie przed czołem lądolodu. Okresowe nagłe zwiększenia energii związane ze wzmożoną ablacją zapisane są jako warstwy grubookruchowych żwirów. Dominują żwiry horyzontalnie warstwowane oraz masywne o różnym stopniu wysortowania przewarstwione osadami piaszczystymi (Sh, Sm) (m.in. stanowisko Górki Duże k. Tuszyna - rys. 4A, stożek marginalny we wsi Łęka w Kotlinie Kolskiej). Mniejszą regularność rytmu ablacji stwierdzono w ozie Rylska w Łaszczynie (rys. 4B) oraz w osadach sandru proksymalnego w Mariance (rys. 4C).

\section{Litotypy średniej energii}

Litotypy średniej energii są spotykane powszechnie: w większości ozów (m.in. w Perzycach - rys. 5A, w Bielikach - rys. 5B, w Muchach, w Łaznowskiej Woli), w wielu kemach (zwłaszcza zachodniej części regionu) oraz w glacifluwialnych wypełnieniach rynien subglacjalnych (Cienia 3 - rys. 5C).

Większość ozów Polski Środkowej charakteryzuje się dominacją osadów średniej energii przepływu. W części z nich występuje bardziej żwirowe jądro typowe dla tego typu form i zbudowane najczęściej z masywnych lub przekątnie warstwowanych żwirów o zróżnicowanej zawartości piaszczystej matriks. Jądro ozowe widoczne jest tylko w nielicznych odsłonięciach, ponieważ znaczna ich część ma głębokość jedynie kilku metrów. Najczęściej spotykane kompleksy osadowe w ozach Polski Środkowej złożone są z występujących naprzemiennie litofacji masywnych żwirów, piasków żwirowych i piasków (Gm, SGm, Sm), przekątnie rynnowo warstwowanych piasków ze żwirem (SGt) oraz warstwowanych horyzontalnie żwirów, piasków żwirowych i piasków (Gh, SGh, Sh). W brzeżnych częściach form często występują deformacje, a najwyższą 

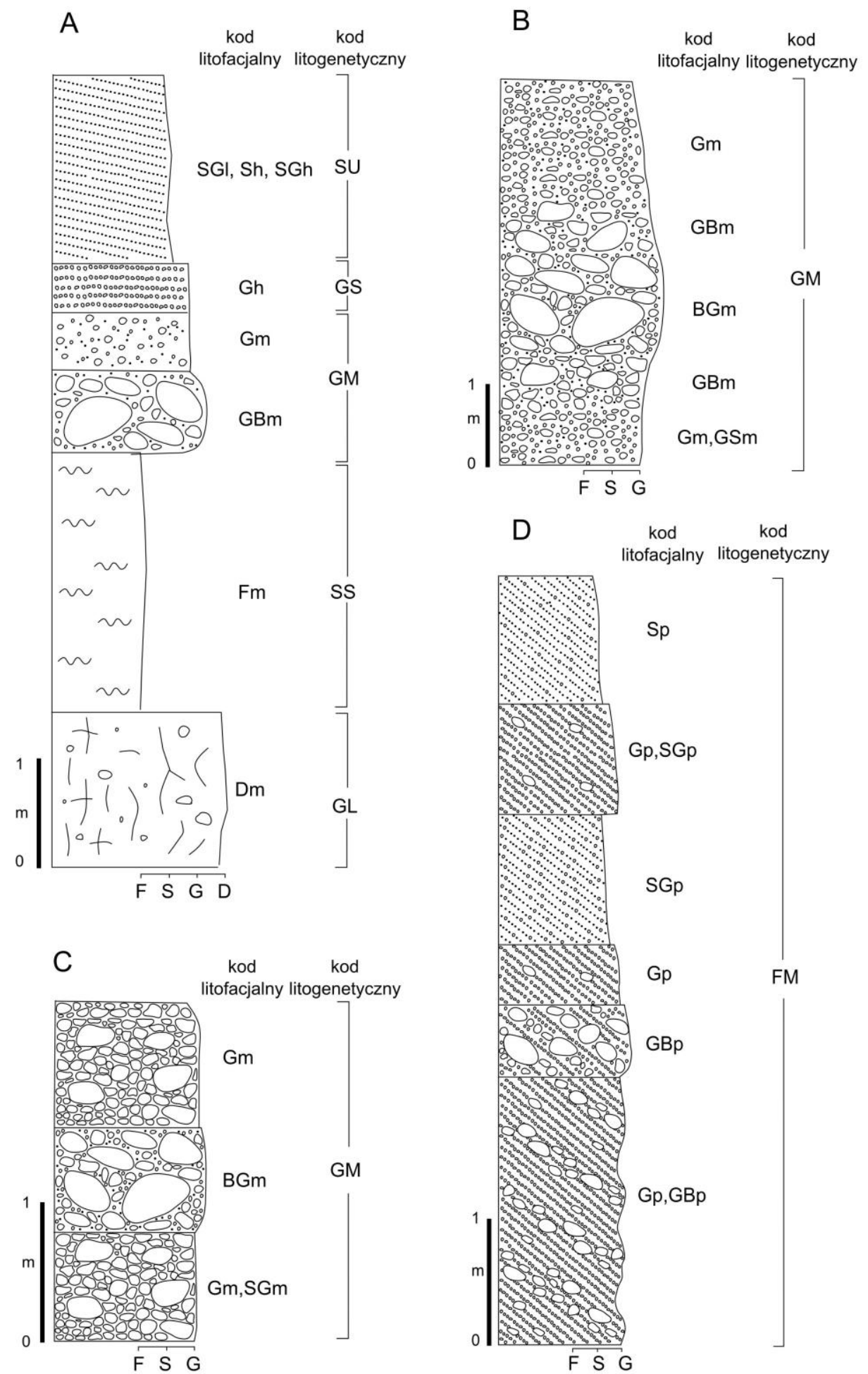

Rys. 3. Profile litofacjalne. A i B - stanowisko Siedlątków - profile osadów warciańskich zachodniego skraju Wysoczyzny Łaskiej, C i D - profile centralnej części ozu Rzymska (wg Frydrych 2016) symbole objaśnione w tab. 1

Lithofacies logs. A and B - Siedlątków site - profiles of the Wartanian sediments of the western edge of the Łask Upland Plain, C and D - central part of the Rzymsko esker (after Frydrych 2016) for details see Tab. 1 

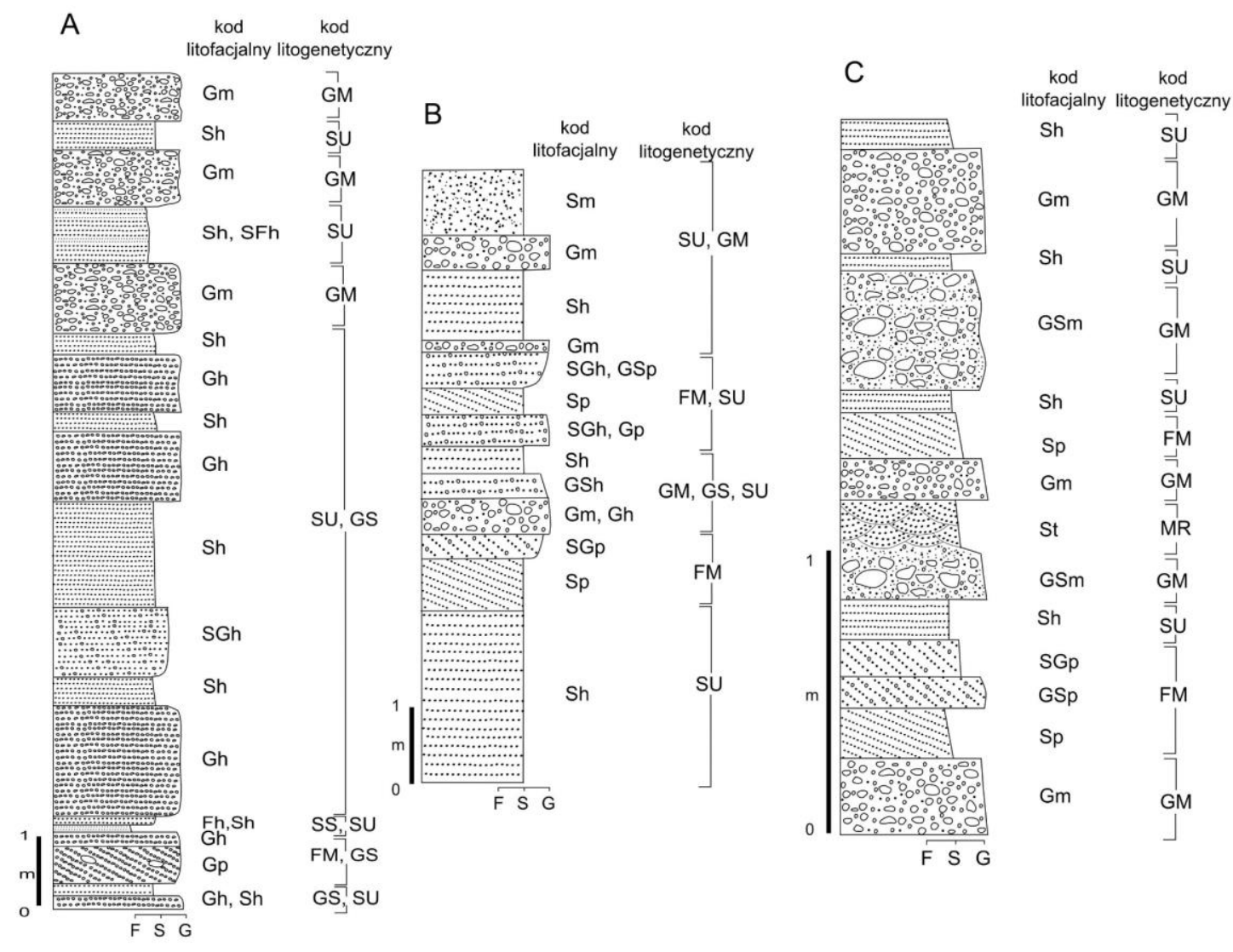

Rys. 4. Profile litofacjalne osadów. A - profile w stanowisku Górki Duże (stożek glacimarginalny), B - Łaszczyn (oz Rzymska), C - Marianka (sandr)

symbole objaśnione w tab. 1

Lithofacies logs. A - Górki Duże site (glacimarginal cone), B - Łaszczyn (Rzymsko esker), C - Marianka outwash plain

symbols explained in Tab. 1

część profilu stanowią osady ablacyjne o różnym stopniu ciągłości i miąższości z reguły nieprzekraczającej $4 \mathrm{~m}$. Znaczna część ozów nadbudowana jest drobnoziarnistymi litofacjami, przekątnie riplemarkowo laminowanych piasków (Sr) oraz horyzontalnie laminowanych piasków i mułów (SFh), powstającymi w środowisku o niskiej energii. Można je uznać $\mathrm{z}$ tego powodu nawet za bardziej typowe dla kemów niż ozów. Świadczy to o zmianie warunków akumulacji osadów po otwarciu tunelu (zapadnięciu się jego stropu) i poszerzeniu przetainy lodowej. Jest prawdopodobne, że w Polsce Środkowej znaczna liczba ozów (być może większość) ma nadbudowę kemową, a kemy - zakorzenienie w rynnie subglacjalnej, co wskazuje na ich złożoną genezę i bywa utrudnieniem $w$ rozpoznaniu form podczas obserwacji osadów w odsłonięciach o ograniczonej głębokości.

\section{Litotypy niskiej energii}

Litotypy niskiej energii są charakterystyczne dla kemów glacilimnicznych oraz osadów zbiorników zastoiskowych (rys. 6). Największym obszarem występowania tych litotypów jest wschodnia część Wysoczyzny Łódzkiej i Wysoczyzna Rawska, w szczególności zlewnia górnej i środkowej Rawki. Występują tutaj różnego rodzaju i wielkości kemy (wały, pagórki, plateaus, terasy), przy czym nawet formy bardzo rozległe, jak wał pukiniński o długości około 6 kilometrów i wysokości do 30 metrów, zbudowane są w przewadze $\mathrm{z}$ litofacji drobnopiaszczystych i mułowych. Utwory te powstały w rozległych zbiornikach pośród zdezintegrowanej pokrywy lądolodu, wskutek akumulacji stożków, delt, dystalnych rzek roztokowych oraz w wyniku akumulacji w stojącej wodzie (Rdzany 2006, 2009; Jaksa 2006). 


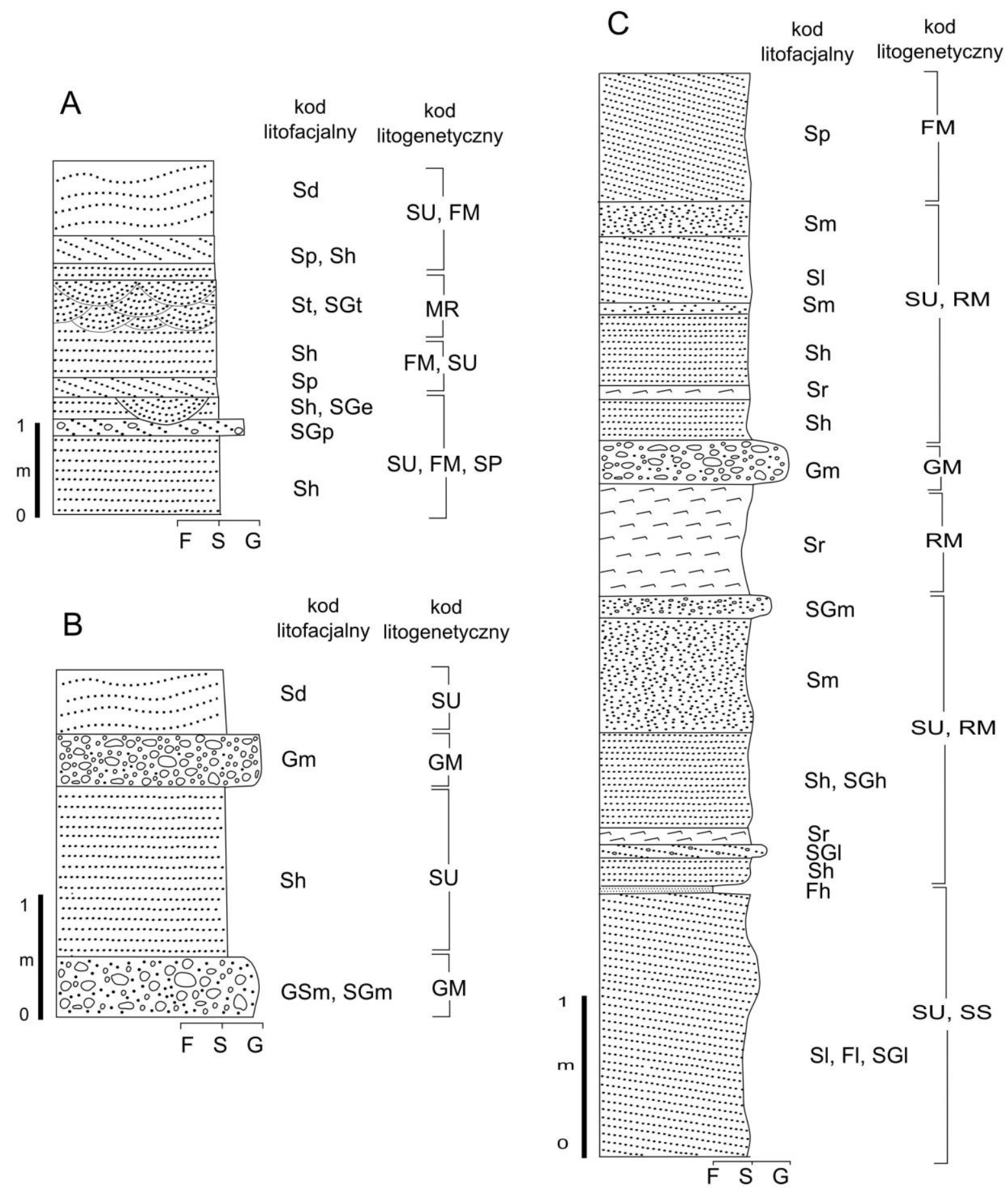

Rys. 5. Profile litofacjalne. A - oz w Perzycach, B - oz w Bielikach k. Bełchatowa, $\mathrm{C}$ - glacifluwialne wypełnienie rynny subglacjalnej w stanowisku Cienia $3 \mathrm{w}$ dolinie Pokrzywnicy symbole objaśnione w tab. 1

Lithofacies logs. A - esker in Perzyce, B - esker in Bieliki near Bełchatów, C - glacifluvial fill of a subglacial channel at site Cienia 3 in the Pokrzywnica valley symbols explained in Tab. 1 

A
kod
kod
litofacjalny litogenetyczny

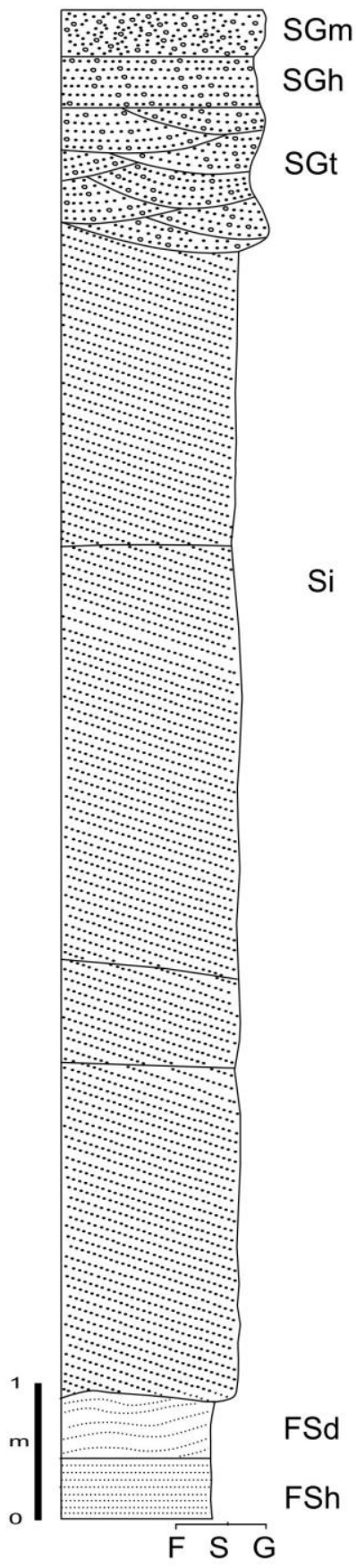

B

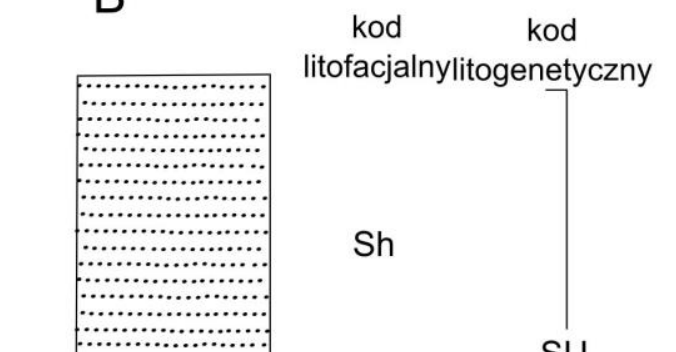

$\mathrm{Sm}$

Sh

$\mathrm{Sm}$

$\mathrm{Sp}$

$$
\text { SU }
$$

$\left.\right|_{0} \mid$

F S G

$\mathrm{Sh}$
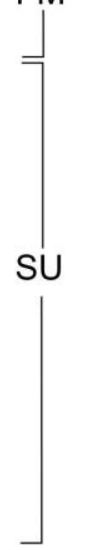

Rys. 6. Profile litofacjalne. A - centralna część wału kemowego o strukturze delty w Rawie Mazowieckiej, B - centralna część kemu w Zapadach k. Skierniewic symbole objaśnione w tab. 1

Lithofacies logs. A - central part of the kame ridge in Rawa Mazowiecka, B - central part of kame in Zapady near Skierniewice symbols explained in Tab. 1 


\section{Dyskusja i wnioski}

Litotypy w sedymentologii wydzielane są na podstawie ścisłej charakterystyki teksturalnej i strukturalnej. Litofacje wyróżniane w ich obrębie mają dokładną charakterystykę jakościową, a nawet ilościową (udział procentowy). Wyodrębnione są na przykład litotypy stożków spływowych, litotypy piaskodennych i żwirodennych roztok i in. (Zieliński 2014). Również w stratygrafii wydzielanie jednostek litostratygraficznych (warstw, ogniw, formacji) uwarunkowane jest udokumentowaniem określonej kombinacji litotypów (Marks i in. 2014).

Mając na uwadze różne uwarunkowania teorii sedymentologii i stratygrafii, autorzy podjęli próbę wydzielenia typów profili pod względem poziomu energii, zakładając, że prace te mogą pomóc rozwiązać szereg problemów paleogeograficznych. Należą do nich m.in. trudności: z wyznaczeniem zasięgów lądolodów różnej rangi, z określaniem zasięgu i inwentarza form marginalnych, z ustaleniem genezy niektórych form, a nawet ich zespołów.

Wydaje się, że optymalnym rozwiązaniem byłoby wyliczanie mocy paleostrumienia, tym bardziej że opracowano już szereg sposobów ustalania tej wielkości (Zieliński 2014). Stosowanie podanych procedur jest jednak wskazane przy rozwiązywaniu konkretnych, szczegółowych kwestii w badaniach wybranych form czy zespołów litofacji. Do rozpracowywania problemów paleogeograficznych większej skali przestrzennej autorzy proponują jednak stosunkowo proste grupowanie profili osadów poddanych uprzednio analizie litofacjalnej i litogenetycznej.

Przeprowadzone w różnych stanowiskach badania pozwalają zaliczyć opracowane profile do jednej z czterech grup - typów/zakresu poziomu energii zapisanego w cechach osadu. Taki zabieg, przeprowadzony $\mathrm{W}$ zasięgu badanej formy lub w granicach zespołu form, często umożliwia ustalenie przeciętnego poziomu energii, co może być bardzo użyteczne w różnych rekonstrukcjach paleogeograficznych.

Ustalenie na przykład cech przestrzennych struktur związanych z zapisem procesów bardzo wysokiej energii, w tym procesów określanych jako ekstremalne (osady stanowisk Siedlątków i Rzymsko), pozwoliło zdaniem autorów na zidentyfikowanie zapisu sedymentacji $\mathrm{w}$ obrębie strefy marginalnej, nawet przy niezbyt wyrazistej morfologii terenu. Należy bowiem zauważyć, że na tym obszarze, w pasie towarzyszącym od południa pradolinie warszawsko-berlińskiej w zasięgu dorzecza Warty, były wątpliwości co do występowania typowych glacjalnych form marginalnych. Na przykład według Krzemińskiego (1997) jest to tzw. strefa kalisko-niemysłowska obszar zaniku arealnego lądolodu warty z kemami, jako formami dominującymi. Jakkolwiek trudno kwestionować istnienie pojedynczych kemów, to jednak dowody na wystąpienie powodzi lodowcowej, pobliski wylot tunelu subglacjalnego, w którym powstawał oz Rzymska, a także wysokoenergetyczna akumulacja stożka marginalnego w Łęce, są wyraźnymi przesłankami zapisu procesów związanych z dynamiką aktywnego, ulegającego oscylacjom czoła lądolodu, sprzyjającego gwałtownym wezbraniom wód roztopowych. To dodatkowe argumenty za wyróżnieniem w tym rejonie zapisu aktywności pomaksymalnej lądolodu warty, nazwanej subfazą bzury (Rdzany 2009). Powstanie kemów w ostatnim etapie deglacjacji nie zatarło tu zapisu bardzo aktywnego lodu lodowcowego.

Z kolei udokumentowanie licznych profili, reprezentujących litotypy niskiej energii $\mathrm{w}$ kemach zlewni górnej Rawki pozwoliło na wskazanie rozległych stref akumulacji niskoenergetycznej, a jednocześnie - na wyznaczenie rozległego obszaru deglacjacji arealnej we wschodniej części Wzniesień Łódzkich. Wystąpiła koncentracja sedymentacji zbiornikowej i sedymentacji dystalnych rzek roztokowych w zasięgu kotlinowatego obniżenia spągu lądolodu (por. Rdzany 1997). Spotykane w tym rejonie struktury związane z zapisem procesów wysokoenergetycznych mają bardzo ograniczony zasięg przestrzenny. Pozwala to wykluczyć istnienie strefy czołowomorenowej, która rozdzielałaby występujący we wschodniej części Wzniesień Łódzkich - wyjątkowo rozległy i liczny nawet na skalę Niżu Polskiego - zespół kemów.

Przeprowadzone badania $\mathrm{z}$ zastosowaniem grupowania profili litofacjalnych i litogenetycznych wskazują na potrzebę dalszego testowania i doskonalenia przedstawionych metod, w szczególności na obszarach występowania form słabo jeszcze poznanych. Taki niezadowalający stan badań występuje w strefie zasięgów maksymalnych i recesyjnych zlodowaceń odry i warty, a spośród kategorii form do dokładniejszego rozpoznania należą: sandry, moreny czołowe (stożki marginalne), różne formy złożone i przejściowe oraz rynny subglacjalne.

Pełniejsze rozpoznanie powtarzających się sekwencji cech litologicznych w różnych zespołach form może być także pomocne w badaniach 
stratygrafii plejstocenu zarówno Polski Środkowej, jak i innych obszarów niżowych, które uległy zlodowaceniom kontynentalnym.

\section{Podziękowania}

Autorzy serdecznie dziękują Recenzentom artykułu za konstruktywne uwagi.

\section{Literatura}

Balińska-Wuttke K. 1960. Geomorfologia obszaru między Skierniewicami a Rawą Mazowiecką. Prace Geograficzne IG PAN 23: 1-93.

Baraniecka M.D., Sarnacka Z. 1971. Stratygrafia czwartorzędu i paleogeografia dorzecza Widawki. Biuletyn Państwowego Instytutu Geologicznego 254: 157-259.

Ber A. 2006. Mapa glacitektoniczna Polski 1:1 000 000. PIG, Warszawa.

Brennand T.A. 1994. Macroforms, large bedforms and rhythmic sedimentary sequences in subglacial eskers, south-central Ontario: implications for esker genesis and meltwater regime. Sedimentary Geology 91,1-4: 9-55.

Czubla P. 2001. Eratyki fennoskandzkie w utworach czwartorzędowych Polsce Środkowej i ich znaczenie stratygraficzne. Acta Geographica Lodziensia 80: 1-174.

Czubla P. 2015. Eratyki fennoskandzkie w osadach glacjalnych Polski i ich znaczenie badawcze. Wyd. UŁ Łódzkiego, Łódź: 1-335.

Czubla P., Forysiak J., Twardy J. 2013. Diamicton in Besiekierz (Central Poland) - how to avoid misinterpretation of superposition in Quaternary geology. Geological Quarterly 57(4): 629-636. doi: 10.7306/gq.1116.

Czyż J., Kamiński J., Forysiak J., Klatkowa H. 2008. Szczegółowa mapa geologiczna Polski 1:50 000, arkusz Dobra. PIG, Warszawa.

Dadlez R., Jaroszewski W. 1994. Tektonika. Wydawnictwo Naukowe PWN, Warszawa: 1-745.

Delaney C. 2001. Esker Formation and the Nature of Deglaciation: the Ballymahon Esker, Central Ireland. North West Geography 1,2: 23-33.

Dylik J. 1952. Peryglacjalne struktury w plejstocenie środkowej Polski. Biuletyn Państwowego Instytutu Geologicznego 66: 53-113.

Dylik J. 1953. O peryglacjalnym charakterze rzeźby środkowej Polski. Acta Geographica Universitatis Lodziensis 4: 1-109.

Dylikowa A. 1952. O metodzie badań strukturalnych w morfologii glacjalnej. Acta Geographica Universitatis Lodziensis 3: 1-74.

Dylikowa A. 1956. Kliny zmarzlinowe w Sławęcinie. Biuletyn Peryglacjalny 3: 47-59.

Frydrych M. 2014. Rekonstrukcja zdarzeń zapisanych w osadach odsłonięcia klifu w Siedlątkowie nad zbiornikiem Jeziorsko. Maszynopis pracy magisterskiej. Katedra Geografii Fizycznej UŁ, Łódź: 1-84. http://hdl.handle.net/11089/6860

Frydrych M. 2016. Structural and textural response to dynamics of fluvioglacial processes of the Rzymsko esker sediments, Central Poland. Geology, Geophysics \& Environment 42(4): 411428.

Goździk J. 1995a. Wybrane metody analizy kształtu ziarn piasków dla celów paleogeograficznych i stratygraficznych. W: E. Mycielska-Dowgiałło, J. Rutkowski (red.) Badania osadów czwartorzędowych. Wybrane metody i interpretacja wyników. Wydz. Geogr. i Studiów Regionalnych UW, PIG, Komisja Litologii i Genezy Osadów Czwartorzędowych KBCz PAN, Warszawa: 115-132.

Goździk J. 1995b. Periglacial impact on some features of glacial deposits in central Poland. W: J. Ehlers, S. Kozarski, P. Gibbard (red.) Glacial Deposits in North-East Europe. A.A. Balkema, Rotterdam: 319-327.

Górska-Zabielska M., Wachecka-Kotkowska L. 2015. Petrografia żwirów i eratyki przewodnie w osadach wodnolodowcowych jako przesłanki wnioskowania na temat źródeł i kierunków transportu materiału w obszarze między Piotrkowem Trybunalskim, Radomskiem a Przedborzem. Acta Geographica Lodziensia 103: 57-78.

Jaksa A. 2003. Zmienność sedymentacji w ozie. Stanowisko Rzymsko. W: B. Gruszka (red.) Terenowe warsztaty sedymentologiczne „Kemy i ozy - stary problem w nowym, sedymentologicznym ujęciu", 08-12 września 2003. Uniwersytet Śląski, Sosnowiec: 40-45.

Jaksa A. 2006. Środowiska sedymentacyjne kemów regionu łódzkiego. Acta Geographica Lodziensia 92: 1-95.

Jaksa A., Rdzany Z. 2002. Sedymentologiczny zapis dynamiki deglacjacji Wysoczyzny Rawskiej na przykładzie Wału Rylska. Acta Universitatis Nicolai Copernici, Geografia 32, 109: 169181.

Kenig K. 1999. Analiza składu mineralogiczno-petrograficznego frakcji piaszczystej. W: L. Marks, A. Ber (red.) Metodyka opracowania Szczegółowej mapy geologicznej Polski w skali 1:50 000. PIG, Warszawa, 60-61.

Klajnert Z. 1966. Geneza Wzgórz Domaniewickich i uwagi o sposobie zaniku lodowca środkowopolskiego. Acta Geographica Lodziensia 23: $1-136$.

Klajnert Z. 1978. Zanik lodowca warciańskiego na Wysoczyźnie Skierniewickiej i jej północnym przedpolu. Acta Geographica Lodziensia 38: $1-149$.

Klajnert Z. 1984. Analysis of kames for palaeogeographical reconstructions. Boreas 13,2: 95-109.

Klatkowa H. 1972. Paleogeografia Wyżyny Łódzkiej i obszarów sąsiednich podczas zlodowacenia 
warciańskiego. Acta Geographica Lodziensia 28: $1-220$.

Klatkowa H. 1982. Utwory ablacyjne w regionie łódzkim. Acta Geographica Lodziensia 45: 1-75.

Klatkowa H. 1993. Niektóre cechy glacigenicznych osadów warty w środkowej Polsce. Acta Geographica Lodziensia 65: 99-140.

Klatkowa H. 1996. Elementy glacitektoniczne w budowie geologicznej i rzeźbie podłódzkiej części środkowej Polski. Acta Geographica Lodziensia 72: 7-103.

Krzemiński T. 1965. Przełom doliny Warty przez Wyżynę Wieluńską. Acta Geographica Lodziensia 21: 1-171.

Krzemiński T. 1974. Geneza młodoplejstoceńskiej rzeźby glacjalnej w dorzeczu środkowej Warty. Acta Geographica Lodziensia 33: 1-171.

Krzemiński T. 1997. Cechy rozwoju i zaniku lądolodu warciańskiego w środkowej Polsce. Acta Universitatis Lodziensis, Folia Geographica Physica 1: 47-65. http://hdl.handle.net/11089/2878

Lencewicz S. 1927. Dyluwium i morfologia środkowego Powiśla. Prace Państwowego Instytutu Geologii t. II, 2: 1-220.

Lisicki S. 2003. Litostratygrafia i litotypy glin lodowcowych plejstocenu dorzecza Wisły. Prace Państwowego Instytutu Geologicznego 177: 1-105.

Lüttig G. 1958. Methodische Fragen der Geschiebeforschung. Geologisches Jahrbuch 75: 361-418.

Maizels J.K. 1997. Jökulhlaup deposits in proglacial areas. Quaternary Science Reviews 16: 793819.

Marks L. 2005. Pleistocene glacial limits in the territory of Poland. Przegląd Geologiczny 53,10/2: 988-993.

Marks L., Ber A., Lindner L. 2014. Zasady polskiej klasyfikacji i terminologii stratygraficznej czwartorzędu. Polska Akademia Nauk, Komitet Badań Czwartorzędu: 1-72.

Miall A.D. 1978. Lithofacies types and vertical profile models in braided river deposits: a summary. W: A.D. Miall (red.) Fluvial Sedimentology. Canadian Society of Petroleum Geologists: 597-604.

Miall A.D. 1985. Architectural-element analysis: a new method of facies analysis applied to fluvial deposits. Earth-Science Reviews. 22: 261308.

Nalewajko J. 1982. Zróżnicowanie litofacjalne warciańskich glin morenowych w regionie łódzkim. Acta Geographica Lodziensia 44: 1-159.

Orłowska A. 2017. Osady plejstoceńskich powodzi lodowcowych w strefie marginalnej lądolodu warty we wschodniej Polsce. XXIV Konferencja Naukowo-Szkoleniowa Stratygrafia Czwartorzędu Polski „Czwartorzęd pogranicza niżu i wyżyn w Polsce Środkowej”, 4-8 września 2017 r., Wawrzkowizna k/Bełchatowa: 111113.
Rdzany Z. 1997. Kształtowanie rzeźby terenu między górną Rawką a Pilicą w czasie zaniku lądolodu warciańskiego. Acta Geographica Lodziensia 73: $1-146$.

Rdzany Z. 2006. Osady deglacjacyjne zlodowacenia warty we wschodniej części regionu łódzkiego. Przeglad Geologiczny 54,4: 343-351.

Rdzany Z. 2009. Rekonstrukcja przebiegu zlodowacenia warty w regionie łódzkim. Wyd. UŁ, Łódź: $1-310$.

Rdzany Z. 2015. The role of the paraglacial environment in the transformation of glacial Wartanian relief in Poland. Bulletin of Geography. Physical Geography Series 8: 33-45. doi: http://dx. doi.org/10.1515/bgeo-2015-0003

Rdzany Z., Frydrych M., Szmidt A., Tarnawska K. 2015. W sprawie genezy i wieku form rzeźby glacjalnej pogranicza Wysoczyzn Kaliskiej i Tureckiej. Acta Universitatis Lodziensis, Folia Geographica Physica 14: 37-53. doi:10.18 778/1427-9711.14.04

Rotnicki K. 1967. Geneza Wzgórz Ostrzeszowskich. Badania Fizjograficzne nad Polska Zachodnia 19: 93-154.

Rotnicki K. 1976. The theoretical basis for a model of the origin of glaciotectonic deformations. Questiones Geographicae 3: 103-139.

Różycki S.Z. 1961. Middle Poland - general presentation. VIth INQUA Congress, Guide-book of excursion from the Baltic to the Tatras, part II, vol. I, Warszawa: 1-116.

Turkowska K. 1984. Łaznowska Wola. Pozostałości rzeźby glacjalnej w dolinie Miazgi. Przewodnik konferencji „Rozwój sieci dolinnej na Wyżynie Łódzkiej w późnym plejstocenie i holocenie". Wyd. UŁ, Łódź: 93-101.

Turkowska K. 2006. Geomorfologia regionu łódzkiego. Wyd. UŁ: 1-237.

Wachecka-Kotkowska L. 2015. Rozwój rzeźby obszaru między Piotrkowem Trybunalskim, Radomskiem a Przedborzem w czwartorzędzie. Wyd. UŁ, Łódź: 1-128. doi:10.13140/RG.2. 1.3373 .8328

Zaborski B. 1926. Ozy między Grójcem a Odrzywołem. Przegląd Geograficzny 6: 129-133.

Załoba M. 1996. Uwagi dotyczące wykształcenia i mechanizmów deformacji struktur glacitektonicznych w Pagórkach Warciańskich. Acta Geographica Lodziensia 72: 153-210.

Załoba M., Czubla P. 1995. Examples of deformation structures in deposits of different ages in the vicinity of the Uniejów basin and the eastern part of the Turek Plateau. Acta Geographica Lodziensia 68: 197-212.

Zieliński T. 2014. Sedymentologia. Osady rzek i jezior. Adam Mickiewicz University Press, Poznań: 1-594. 


\section{Summary}

The article presents the evolution of experiments with the application of lithological methods in a palaeogeographic reconstruction of glacigenic processes in the area of the old glacial relief in Central Poland, as well as a proposal for a wider use of the lithofacies and the lithogenetic method in connection with determining the energy level record in sedimentation environments.

Progress in broadening the knowledge of the lithology and lithostratigraphy of formations of the Middle Polish Complex, in particular of glacigenic sediments from the Warta Glaciation in Central Poland, dates back to the first years after the Second World War. A more intense development of such research started in the 1960s. New monographs were written in the field of glacial geomorphology and Quaternary geology, devoted mostly or entirely to individual types of Wartanian forms and sediments. Among the researchers of the region who made extensive use of various lithofacies methods, Prof. dr hab. Halina Klatkowa holds a special place.

For more than a decade, the lithofacies analysis method has become more and more commonly used in the research of the described area, which results in increasingly precise palaeogeographic reconstructions. The authors propose to apply this method along with lithogenetic analysis (Miall 1978, 1985; Zieliński 2014), with the simultaneous use of grouping of lithological profiles based on the energy level (range) recorded in the features of the sediments. Using the lithological record method from the point of view of energy level, the authors assumed a division into four main lithotypes: 1) very high, 2) high, 3) medium, and 4) low energy. It was observed that the lithotypes distinguished on this basis reveal connections both with specific types of sedimentation environments and with genetic groups of relief forms.

For example, determining the spatial features of structures related to the record of very high energy processes allows for easier identification of the record of the marginal zone, even if the morphology is not very clear, which is common for areas of old glacial relief. On the other hand, delimitation of zones of low energy accumulation allows for locations of areal deglaciation to be identified within the given glacial lobe. Recurring sequences of lithological features in different form systems can also contribute to research into the Pleistocene stratigraphy of both Central Poland and other regions of the Polish Lowland. 